\title{
PENERAPAN MODEL PEMBELAJARAN BERBASIS MASALAH (PROBLEMBASEDINSTRUCTION) UNTUK MENINGKATKAN HASILBELAJAR MATEMATIKA MATERI PENGERJAAN HITUNG PECAHAN PADA SISWA KELAS VI
}

oleh:

\author{
Hj. WAMPIKA \\ GURU SD NEGERI 87 KENDARI \\ Email: wampikasdn87kendari@gmail.com
}

\begin{abstract}
ABSTRAK
Hasil penelitian yang diperoleh pada siklus I ketuntasan belajar mencapai $65,2 \%$ dan padasiklus II mencapai $82,6 \%$.Persentase aktivitas belajar siswa pada siklusI pertemuan pertama $60 \%$ dan pertemuan kedua $70 \%$ sedangkan persentase aktivitas belajar siswa pada siklus II pertemuan pertama $80 \%$ dan pertemuan kedua $90 \%$. Persentase aktivitas mengajar guru pada siklusI pertemuan pertama $72,5 \%$ dan pertemuan kedua $80 \%$ sedangkan persentase aktivitas belajarsiswa pada siklus II pertemuan pertama $87,5 \%$ dan pertemuan kedua 92,5\%.Berdasarkan hasil penelitian disimpulkan bahwa pelaksanaan model pembelajaran berbasis masalah dapat meningkatkan hasil belajar Matematika siswakelas VI SD Negeri 87 Kendari.Berdasarkan kesimpulan di sarankan agar guru menerapkan model pembelajaran berbasis masalah dalam mengajarkan mata pelajaran di sekolah, karena model pembelajaran ini efektif meningkatkan hasil belajar Matematika siswa secara signifikan.
\end{abstract}

\section{Kata Kunci: Pembelajaran Berbasis Masalah, Pecahan}

\section{PENDAHULUAN}

Masalah pembelajaran pecahan di SD disebabkan karena pada proses pembelajaran guru hanya memberi informasi atau pengetahuan kepada siswa. Dimana siswa hanya mendengarkan penjelasan guru dan kurang aktif dalam proses pembelajaran siswa juga tidak memahami konsepkonsep dari menggunakan pecahan dalam masalah perbandingan dan skala itu sendiri, sehingga berpengaruh pada rendahnya hasil belajar siswa.

Untuk mengantisipasi masalah di atas, guru diharapkan dapat mengembangkan suatu model pembelajaran yang dapat meningkatkan kemampuan mengembangkan, menemukan, menyelesaikan dan mengungkapkan masalah siswa itu sendiri, sehingga dapat membuat siswa lebih berperan aktif dalam proses belajar mengajar, mampu menyelesaikan persoalan-persoalan yang diberikan baik itu perindividu maupun perkelompok, guru juga diharapkan dapat memberikan suasana belajar yang lebih menyenangkan dan tidak membosankan, serta memberikan pembelajaran yang optimal, juga mampu membangkitkan dan memelihara minat siswa dalam belajar. Sehingga dapat meningkatkan hasil belajar siswa disekolah. 
Salah satu model pembelajaran yang dapat membantu peserta didik berlatih memecahkan masalah adalah Model Pembelajaran Bedasarkan Masalah (Problem Based-Instruction). Model ini merupakan model pembelajaran yang membawa peserta didik pada masalah autentik (nyata), sehingga peserta didik mampu menyusun pengetahuannya sendiri, menumbuh kembangkan keterampilan yang tinggi dan inquiri, memandirikan peserta didik, dan meningkatkan kepercayaan dirinya (Trianto, 2010: 92). Selain itu model pemebelajaran ini juga memberikan siswa pengalaman dan pengetahuan secara langsung melalui apa yang dilakukan sendiri, bukan dari apa yang dia dengar dari orang lain. Pada model ini, peran guru adalah mengajukan masalah, mengajukan pertanyaan, memberikan kenyamanan suasana berdialog, dan menjadi fasilitator, dimana guru mengajukan masalah yang berupa pertannyaan atau soal memberikan bimbingan pada saat siswa mengerjakan soal yang diberikan serta memberikan suasana belajar yang nyaman pada saat proses pembelajaran berlangsung dikelas.

\section{Model Pembelajaran Berbasis Masalah (Problem Based Instruction)}

Menurut Ibrahim dan M. Nur dalam Setiawidjayanti (2012: 4) berbagai pengembangan pengajaranBerbasis Masalah (Problem Based Instruction) telah memberikan model pengajaran yang memiliki karakteristik sebagai berikut:

a. Pengajuan pertanyaan atau masalah

b. Berfokus antara keterkaitan disiplin

c. Menganalisis produk atau karya dan memamerkan

d. Kerja sama

$$
\text { Adapun sintaks model }
$$

Pembelajaran Berbasis Masalah, dapat dilihat dalam tabel 2.1 seperti berikut ini.

Tabel 1. Sintaks model pembelajaran berbasis masalah

\begin{tabular}{|c|c|}
\hline Fase & Tingkah Laku Guru \\
\hline $\begin{array}{l}\text { Fase } 1 \\
\text { Orientasi siswa kepada masalah }\end{array}$ & $\begin{array}{l}\text { Guru menjelaskan tujuan pembelajaran, } \\
\text { menjelaskan logistic yang dibutuhkan, } \\
\text { memotivasi siswa terlibat pada aktivitas } \\
\text { pemecahan masalah }\end{array}$ \\
\hline $\begin{array}{l}\text { Fase } 2 \\
\text { Mengorganisasikan siswa untuk } \\
\text { belajar }\end{array}$ & $\begin{array}{l}\text { Guru membantu siswa mendefinisikan dan } \\
\text { mengorganisasikan tugas belajar yang } \\
\text { berhubungan dengan masalah tersebut }\end{array}$ \\
\hline $\begin{array}{l}\text { Fase } 3 \\
\text { Membimbing penyelidikan individu } \\
\text { maupun kelompok }\end{array}$ & $\begin{array}{l}\text { Guru mendorong siswa untuk mengumpulkan } \\
\text { informasi yang sesuai, melaksananakan } \\
\text { eksperimen, untuk mendapatkan penjelasan } \\
\text { dan pemecahan masalah }\end{array}$ \\
\hline $\begin{array}{l}\text { Fase } 4 \\
\text { Mengembangkan dan menyajikan } \\
\text { hasil karya }\end{array}$ & $\begin{array}{l}\text { Guru membantu siswa dalam merencanakan } \\
\text { dan menyiapkan karya yang sesuai seperti } \\
\text { laporan, video, dan model serta membantu } \\
\text { mereka untuk berbagi tugas dengan temannya }\end{array}$ \\
\hline
\end{tabular}




\begin{tabular}{ll}
\hline Fase 5 & Guru membantu siswa untuk melakukan \\
Menganalisis dan mengevaluasi & refleksi atau evaluasi terhadap penyelidikan \\
proses pemecahan masalah & mereka dan proses yang mereka gunakan
\end{tabular}

(Marpaung, 2002: 24)

Fase-fase tersebut di atas, kemudian dikembangkan sesuai dengan kebutuhan pelaksanaan penelitian ini. Fase-fase tersebut adalah sebagai berikut:

Fase 1 : Persiapan

Fase 2 : Pembentukan Kelompok

Fase 3 : Diskusi Masalah

Fase 4 : Memamerkan produk/karya

Fase 5 : Memberikan kesimpulan/evaluasi

\section{METODE PENELITIAN}

\section{Jenis Penelitian}

Penelitian ini termasuk dalam jenis penelitian tindakan kelas. Ciri utama dalam penelitian tindakan kelas yaitu adannya tindakan-tindakan (aksi) tertentu serta adanya siklus untuk memperbaiki proses pembelajaran di kelas (Mukhtar, 2000: 7).

\section{Setting Penelitian}

Penelitian ini telah dilaksanakan pada semester genap tahun pelajaran 2019/2020 dikelas VI SD Negeri 87 Kendari.

\section{Subjek Penelitian}

Subyek penelitian adalah guru dan siswa kelas VI SD Negeri 87 Kendari.yang terdaftar pada semestergenap tahun ajaran 2016/2017 yang berjumlah 23 orang siswa dan terdiri dari 13 siswa peremopuan dan 10 siswa laki-laki.

\section{Faktor yang Diteliti}

Faktor-faktor yang akan diteliti dalam penelitian ini adalah sebagai berikut:

1. Faktor siswa yaitu untuk melihat bagaimana perhatian keaktifan dan kreativitas siswa dalam proses belajar mengajar serta hasil belajar.

2. Faktor guru yaitu untuk melihat bagaimana persiapan guru dalam menyiapkan materi serta model yang digunakan dalam model pembelajaran di atas.

\section{Rencana Tindakan}

Adapun pelaksanaan tindakan tersebut mengikuti prosedur penelitian tindakan kelas sebagai berikut:
a. Perencanaan
b. Pelaksanaan tindakan
c. Observasi dan evaluasi
d. Refleksi

Skema dari pelaksanaan penelitian tindakan kelas dapat dilihat pada skema berikut: 
Gambar 1 Skema Penelitian Tindakan Kelas (Tim Pelatih Proyek PGSM, 1999:27)

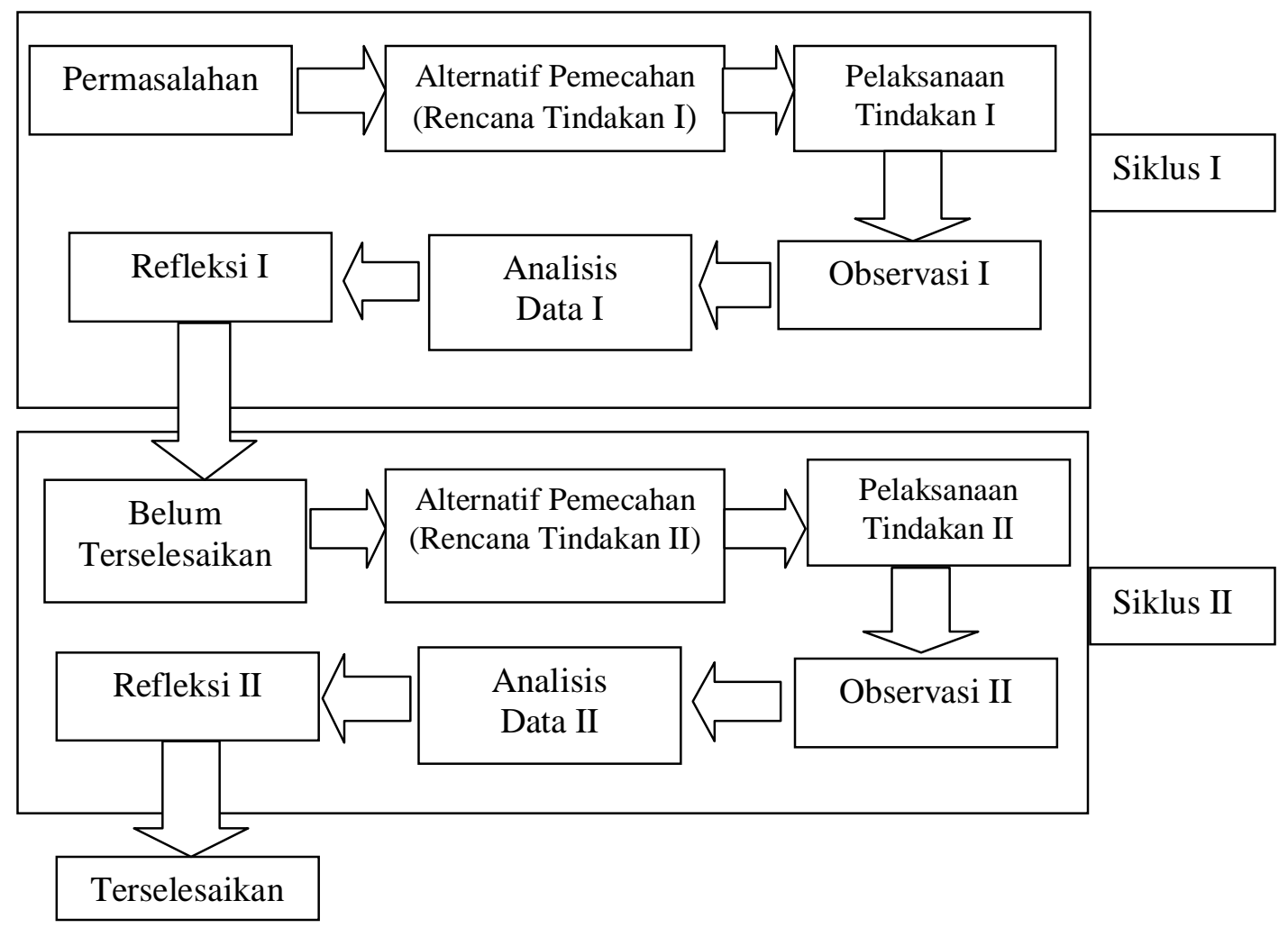

\section{Data dan Teknik Pengumpulan Data}

\section{Data}

Data yang digunakan dalam penelitian ini adalah data kualitatif dan kuantitatif. Data kualitatif berupa pelaksanaan pendekatan pembelajaran PBI oleh guru matematika Kelas VI SD Negeri 87 Kendari.dengan menggunakan lembar observasi dan jurnal refleksi diri. Sedangkan data kuantitatif diambil dengan menggunakan tes hasil belajar matematika.

\section{Sumber Data}

Sumber data dalam penelitian ini adalah guru mata pelajaran matematika yang telah menerapkan pendekatan pembelajaran PBI dan siswa Kelas VI SD Negeri 87 Kendari.

\section{Teknik Pengumpulan Data}

Data tentang proses pelaksanaan model pembelajaran Berbasis Masalah (Problem Based Instruction) diambil dengan menggunakan lembar observasi.

1. Pemberian tes prestasi belajar kepada siswa untuk memperoleh data prestasi belajar matematika pada materi Menggunakan pecahan dalam masalah perbandingan dan skala.

2. Data tentang refleksi diri diambil dengan menggunakan lembar observasi aktivitas guru dan siswa.

\section{Analisis Data}

Teknik analisis data dalam penelitian ini adalah statistik deskriptif untuk menghitung rerata perolehan nilai siswa pada setiap siklus. 


\section{Indikator Kinerja}

IndikatorKinerja dalam penelitian ini ada dua macam. Indikator tersebut adalah sebagai berikut:

a. Aktivitas siswa dan aktivitas guru dikatakan baik apabila $\geq 80 \%$ aspek dalam rencana perbaikan pembelajaran telah terlaksana.

b. Hasil belajar siswa dikatakan berhasil apabila $\geq 75 \%$ siswa telah mencapai nilai $\geq 65$, yang merupakan standar nilai Kriteria Ketuntasan Minimal

\section{HASIL DAN PEMBAHASAN}

\section{Hasil Belajar Siswa}

Untuk memperoleh hasil belajar, dilakukan evaluasi atau penilaian yang merupakan tindak lanjut atau cara mengukur tingkat penguasaan siswa. Dimana evaluasi atau tes yang diberikan setelah pembelajaran usai. Hal ini sejalan dengan pendapat Abdurrahman (dalam Jihad, 2010:14) menyatakan "hasil belajar adalah kemampuan yang diperoleh anak setelah melalui kegiatan belajar". Sedangkan menurut Juliah (dalam Jihad, 2010:15) menyatakan "hasil belajar adalah segala sesuatu yang menjadi milik siswa sebagai akibat dari kegiatan belajar yang dilakukannya".

Berdasarkan hasil penelitian yang telah dilakukan menunjukkan bahwa dengan menerapkan model pembelajaran Berbasis masalahdalam pembelajaran memiliki dampak positif dalam meningkatkan hasil belajar matematika siswa pada materi perbandingan dan skala di kelas VI SD Negeri 87 Kendari. . Hal ini dapat dilihat dari adanya peningkatan hasil belajar siswa pada setiap siklus. Ratarata hasil tes siklus I adalah 67,7 dengan presentase ketuntasan $65,2 \%$. Namun nilai tersebut belum mencapai standar indikator yang telah ditentukan. Kemudian pada siklus II, rata-rata hasil tes siklus II adalah 73,9 dengan presentase ketuntasan $82,6 \%$. Hal tersebut menunjukkan bahwa hasil belajar siswa telah mencapai indikator yang telah ditetapkan yaitu $75 \%$ siswa telah memperoleh nilai $\geq 65$. Lebih jelasnya, perbandingan ketunasan belajar siswa pada siklus I dan siklus II dapat dilihat pada tabel 4.7. berikut:

Tabel 1. Ketuntasan Hasil Belajar Siswa Secara Klasikal Setiap Siklus

\begin{tabular}{clcc}
\hline Siklus & $\begin{array}{l}\text { Hasil } \\
\text { Belajar }\end{array}$ & $\begin{array}{c}\text { Jumlah } \\
\text { Siswa }\end{array}$ & Persentase \\
\hline \multirow{2}{*}{ I } & Tuntas & 15 & $65,2 \%$ \\
\cline { 2 - 4 } & $\begin{array}{l}\text { Tidak } \\
\text { Tuntas }\end{array}$ & 8 & $34,8 \%$ \\
\hline \multirow{2}{*}{ II } & Tuntas & 19 & $82,6 \%$ \\
\cline { 2 - 4 } & $\begin{array}{l}\text { Tidak } \\
\text { Tuntas }\end{array}$ & 4 & $17,4 \%$ \\
\hline
\end{tabular}

\section{Kegiatan Siswa dalam Pembelajaran}

Pada penelitian ini, siswa dibagi dalam 5 kelompok. Setiap kelompok terdiri dari 4-6 siswa. Pembentukan kelompok dilakukan dengan mempertimbangkan perbedaan kemampuan serta jenis kelamin. Hal ini sejalan dengan yang dikemukakan oleh Arends (dalam Trianto 2010: 65) menyatakan bahwa kelompok dibentuk dari siswa yang mempunyai kemampuan tinggi, sedang, dan rendah serta bila memungkinkan anggota kelompok berasal dari ras, budaya, suku dan jenis kelamin yang beragam. Analisis hasil observasi kegiatan siswa dalam pembelajaran menunjukkan bahwa pembelajaran dengan penerapan 
model pembelajaran Berbasis masalahmemiliki dampak positif dalam meningkatkan hasil belajar siswa. Hal ini dapat dilihat dari peningkatan hasil observasi kegiatan belajar siswa dari setiap pertemuan ke pertemuan selanjutnya.

Berdasarkan hasil observasi pada siklus I, kegiatan belajar siswa belum terlaksana dengan baik dan masih terdapat kekurangan-kekurangan yang harus diperbaiki. Hal ini terlihat dari hasil observasi yang dilakukan yang menunjukkan masih ada hal-hal belum sepenuhnya terlaksana secara maksimal diantaranya: (1) tidak semua siswa memberikan jawaban terhadap apersepsi dan motivasi yang dilakukan guru, (2) tidak semua siswa mendengarkan penjelasan guru tentang tujuan pembelajaran, (3) tidak semua siswa memperhatikan penjelasan materi dari guru, (4) tidak semua siswa mengerjakan LKS, (5) tidak semua siswa dapat berdiskusi secara baik dengan anggota kelompoknya, (6) masih ada beberapa siswa yang takut maju ke depan kelas untuk menuliskan hasil jawabannya, (7) belum semua siswa memperhatikan penjelasan guru tentang jawaban yang masih salah, (8) siswa masih banyak yang belum berani mengemukakan kesulitannya, (9) siswa kurang dilibatkan dalam membuat kesimpulan pelajaran.

Berdasarkan kekurangankekurangan tersebut, maka penelitian dilanjutkan pada siklus II. Pada siklus II siswa sudah dapat mengikuti pembelajaran dengan lebih baik, hal tersebut dapat dilihat dari meningkatnya hasil observasi siswa yaitu dari $80 \%$ pada pertemuan pertama menjadi $90 \%$ pada pertemuan kedua.

\section{Kegiatan Guru Dalam Pembelajaran}

Analisis hasil observasi kegiatan siswa dalam pembelajaran menunjukkan bahwa pembelajaran dengan penerapan model pembelajaran Berbasis masalahmemiliki dampak positif dalam meningkatkan kualitas kegiatan guru. Hal ini terlihat dari hasil observasi kegiatan guru pada setiap pertemuan. Pada siklus I, persentase kegiatan mengajar guru yaitu $72,5 \%$ pada pertemuan pertama dan meningkat menjadi $80 \%$ pada pertemuan kedua. Namun disadari masih terdapat kekurangan-kekurangn yang masih perlu diperbaiki, diantaranya: (1) guru menyampaikan materi pelajaran kurang sistematis dan agak cepat, (2) guru tidak membimbing semua siswa yang mengalami kesulitan, (3) guru tidak meminta siswa menanyakan materi pelajaran yang belum dimengerti, (4) guru tidak melibatkan siswa dalam membuat kesimpulan materi pelajaran. Berdasarkan kekurangan yang ada pada siklus I maka pada siklus II peneliti lebih menitikberatkan perbaikan kekurangan tersebut agar pembelajaran berjalan lancar dan efektif.

\section{KESIMPULAN DAN SARAN}

\section{Kesimpulan}

Berdasarkan hasil observasi, evaluasi dan pembahasan yang telah dilakukan dapat disimpulkan sebagai berikut:

1. Penggunaan model pembelajaran berbasis masalah dapat meningkatkan hasil. Hasil tes siklus 1 menunjukkan bahwa 15 dari 23 siswa kelas VI SD Negeri 87 Kendari. telah mencapai nilai $\geq 65$ dengan persentase ketuntasan $65,2 \%$ 
dan rata-rata kelas 67,7. Pada siklus II persentase ketuntasan 82,6\% dengan rata-rata kelas 73,9. Hasil belajar siswa tersebut menunjukkan bahwa indikator kinerja telah tercapai yaitu minimal $75 \%$ siswa memperoleh nilai $\geq 65$.

2. Berdasarkan hasil observasi pada siklus I dan siklus II persentase aktivitas siswa dalam mengikuti pembelajaran berbasis masalah selalu meningkat, ini dapat dilihat dari pencapaian indikator. Pada siklus I aktivitas siswa mencapai $60 \%$ pertemuan pertama dan $70 \%$ pada pertemuan kedua. Pada siklus II meningkat menjadi $80 \%$ dan $90 \%$ pada pertemuuan terakhir. Hal tersebut menunjukkan bahwa siswa telah dapat mengikuti pembelajaran dengan menggunakan model pembelajaran berbasis masalah dengan baik.

3. Dari hasil observasi pada siklus I dan siklus II persentase aktivitas guru dalam pembelajaran berbasis masalah selalu meningkat, ini dapat dilihat dari pencapaian indikator. Pada siklus I aktivitas guru mencapai $72,5 \%$ pertemuan pertama dan $80 \%$ pada pertemuan kedua. Pada siklus II meningkat menjadi $87,5 \%$ dan $92,5 \%$ pada pertemuuan terakhir. Hal tersebut menunjukkan bahwa kegiatan mengajar guru dengan menggunakan model pembelajaran berbasis masalah telah dilaksanakan dengan baik dan mencapai indikator kinerja.

\section{Saran}

Berdasarkan hasil penelitian dan kesimpulan yang telah diuraikan, peneliti mengemukakan beberapa saran sebagai berikut:
1. Bagi guru SD Negeri Negeri 87 Kendari.dapat menggunakan model pembelajaran berbasis masalah sebagai salah satu alternatif dalam meningkatkan hasil belajar siswa pada mata pelajaran Matematika.

2. Berdasarkan pengalaman melaksanakan perbaikan pembelajaran melalui penelitian tindakan kelas, kiranya perlu mengadakan kelompok kerja bagi guru untuk selalu bertukar pikiran dan pengalaman berkenaan dengan masalah dan tugas mengajar seharihari.

3. Bagi peneliti berikutnya, diharapkan dapat menggunakan model pembelajaran yang bervariasi untuk membandingkan penggunaan berbagai tipe pendekatan model pembelajaran untuk mengetahui mana yang lebih efektif untuk diterapkan dalam kegiatan pembelajaran di kelas.

\section{DAFTAR PUSTAKA}

Ibrahim, M., dkk. 2000. Pengajaran Berdasarkan Masalah. Universitas Negeri Surabaya: University Press.

Jihad A. Dan Haris A., 2010. Evaluasi pembelajaran. Yogyakarta: Multi pressindo.

Marpaung Y. dkk. 2002. Pelatihan Terintegrasi Berbasis Kompetensi Guru Mata Pelajaran Mate-Matika. Jakarta. Depdiknas.

Mukhtar, Roni. 2000. Penelitian Tindakan Kelas Bagi Guru. Kendari: Makalah FKIP Unhalu. 
Setiawidjayanti. 2012. Model Pembelajaran Berbasis Masalah untuk Matematika. setiawidjayanti.htm. (Diakses: 30 April 2017)

Suparno, Paul, 2008. Riset Tindakan untuk Pendidik. Jakarta:

Grasindo.

Taruh, Enos. 2003. Konsep Diri dan Motivasi Berprestasi dalam Kaitannya dengan Hasil Belajar Fisika. Jurnal Penelitian dan Pendidikan (hlm.15-29) Gorontalo: IKIP Negeri Gorontalo.. diakses: 12 Mei 2017)

Tim Proyek PGSM, 1999. Penelitian

Tindakan Kelas (Bahan

Penelitian Dosen LPTK dan

Guru Sekolah Menengah).

Jakarta: Depdikbud.

Trianto, 2010. Mendesain Model Pembelajaran InovatifProgresif. Surabaya: Kharisma Putra Utama.

Usman,Muhammad Uzer dan Setiawati Lilis. 1993. Upaya Optimalisasi Kegiatan Belajar Mengajar. Bandung: Remaja Rosdakarya.

Wasis. 2002. Pelatihan Terintegrasi Berbasis Kompetensi Guru Mata Pelajaran. Jakarta: Direktorat Sekolah Lanjutan Tingkat Pertama. 